\title{
Segmentation of Malaysian shoppers by store choice behaviour in their purchase of fresh meat and fresh produce
}

\begin{abstract}
Differences in retail store choice behaviour are examined for the purchase of fresh meat and fresh fruit and vegetables in Malaysia. In purchasing fresh meat, cluster analysis identified two groups of respondents who purchased the majority of the fresh meat they consumed from either modern retail stores or the traditional market. However, with regard to the purchase of fresh fruit and vegetables, cluster analysis identified three groups of respondents (modern retail shoppers, transient shoppers and traditional market shoppers). Although the clusters were labelled using similar terms, several similarities and differences were identified in the respective clusters for each food item. The findings indicate that store choice preference was based on the food product that the consumer intended to purchase.
\end{abstract}

Keywords: consumer behaviour, store choice, fresh meat, fresh fruit and vegetables, Malaysia

\section{Introduction}

Changes are occurring in the retail food sector in both the developed and developing countries. Several push and pull factors are encouraging the emergence of modern retail formats across the globe. These factors include: (1) limited opportunities for supermarkets to expand in their domestic markets (Wong 2007); (2) strong economic growth in regions such as Latin America, Asia and Africa (Goldman et al. 1999; Reardon et al. 2003); (3) the rapid growth in personal disposable income (Shamsudin and Selamat 2005; Reardon et al. 2010); (4) increasing urbanisation (Geuens et al. 2003); and (5) increasing concerns about food safety (Shamsudin and Selamat 2005; Wong 2007) and sustainability (Yiridoe et al. 2005; Harris 2007). As a result, supermarkets and hypermarkets are gradually replacing the role of traditional retail markets, providing consumers with more choice on where and when to shop.

However, despite the rapid expansion of modern retail formats in Asia, the traditional wet markets, farmers markets and small grocery stores continue to provide the main venue for the purchase of fresh food (Hsu and Chang 2002, Maruyama and Trung 2007, Chamhuri and Batt 2009a; 2009b, and Suryadarma et al. 2010). In the traditional markets, many small 
independent retailers are able to fulfil the consumers' specific requirements for variety, assortment, size, quantity and quality (Goldman et al. 1999). In terms of fish and meat items, consumers want the product to be 'live and warm'. Furthermore, traditional retailers offer a high level of personalised service which makes it difficult for consumers to depart from their traditional ways of shopping.

Cheeseman and Wilkinson (1995) describe supermarkets as self-service stores, which offer one stop shopping, value for money and a large product selection in pleasant surroundings. Trappey and Lai (1997) add that most supermarkets have facilities to process fresh foods and use a wide range of refrigerated facilities to hold chilled and frozen product. However, Humphrey (2007) reports that supermarkets generally provide processed, dry and packaged food and non food items. According to Goldman et al. (1999), supermarkets in countries like China, Indonesia, Japan, Singapore and Taiwan are seldom able to dominate the fresh food market due to serious problems associated with the procurement and distribution of fresh food items.

In the past, selecting their preferred retail store was seldom a problem for most Malaysian shoppers as there were few other stores available besides the traditional retail formats. According to Roslin and Melewar (2008), in the 1970's and 1980's, local sundry shops dominated the retail market in Malaysia. However, with the expansion of modern retail outlets, many consumers can now choose from which retail format they wish to purchase.

There is within Malaysia a paucity of literature on store choice behaviour. As a result of the modernisation of the food retail industry in Malaysia, this study attempts to identify the criteria that consumers use in choosing between alternative retail stores for the purchase of fresh meat and fresh fruit and vegetables. Being cognisant that different consumers want different things, and are likely to shop from different stores, this study will endeavour to classify the respondents into discrete segments or clusters.

\section{Store choice behaviour}

According to Sinha and Banarjee (2004), store choice is a cognitive process. It is related to the mental processes involved in gathering knowledge and understanding information to decide where to purchase desired products. In general, a store is chosen based on the self- 
confidence that a shopper has toward the store and the perception that the retailer can provide high quality product at a competitive price and provide good service to the customer.

In determining the preferred place to shop, the consumer's decision to purchase is seldom made on just one attribute, but rather, it involves a set of attributes (Alhemoud 2008). Previous researchers have identified a number of factors influencing consumers' store choice behaviour. Euromonitor (1986) found that the following factors were important in influencing the consumers' choice of store for grocery shopping: clean and hygienic, an extensive range of products, store layout, good parking, low prices, within walking distance, efficient checkout service and quality of food. Engel et al. (1995) considered the location, price, quality of assortment, advertising and promotion, sales personnel, services offered, store atmosphere and post-purchase satisfaction to be the key determinants influencing store choice. Solgaard and Hansen (2003) mentioned several store attributes such as merchandise quality, personnel, store layout, cleanliness and accessibility as being among the most important factors which consumers utilised when evaluating the store they intended to visit.

While these criteria may reflect store choice behaviour and explain why shoppers patronise one store and not another, there is also a need to distinguish consumers' store choice behaviour when purchasing food and non-food items. Wee (1993) confirmed that there is a clear behavioural difference between food and non-food shopping.

In general, the purchase of food is a low product involvement decision. Nevertheless, Beharrell and Denison (1995) found that the level of consumer involvement depends upon the product category. Fresh meat is considered to be a high involvement food product (Verbeke and Vackier 2004). Besides evaluating the product quality attributes, Goldman and Hino (2005), Bonne and Verbeke (2006) and Maruyama and Trung (2007) found that store choice attributes may also influence the consumers' decision to purchase fresh meat. Consumers prefer to shop from those stores they are familiar with and from which they have made a favourable prior purchase as a means of minimising risk. Although purchasing meat from supermarkets is more convenient, consumers preferred to purchase beef from a specialist butcher to obtain a better quality product (McCarthy and O'Reilly 1999). Chamhuri and Batt (2009a) found that consumers who are seeking to purchase fresh meat that is guaranteed Halal preferred to purchase from traditional retailers rather than from modern retail outlets because they trusted the butcher. 
From the literature and an exploratory study (Chamhuri and Batt 2009a; Chamhuri and Batt 2009b), five themes were identified as the major drivers which most influenced the consumer's decision to purchase fresh food from either a modern retail outlet or the traditional market. The factors are not ranked according to importance.

\subsection{The physical attributes of the product}

Freshness is a factor which attracts consumers to shop from both modern and traditional retail outlets. For the purchase of fresh meat, freshness was perceived differently according to the place of purchase. Goldman and Hino (2005) described the freshness of the meat available from the traditional markets as "warm" (just recently slaughtered) and not chilled or frozen. Hsu and Chang (2002) described freshness by the manner in which meat was being presented for sale in the traditional markets, where consumers were given the opportunity to touch the meat before purchase. Conversely, the meat available in most supermarkets and hypermarkets was pre-cut and pre-packaged, and displayed in chillers or freezers (Hsu and Chang 2002). Freshness of the meat purchased from modern retail outlets was determined by the label attached to the product. According to Bonne and Verbeke (2006), the label provided information such as the slaughter date, the date the meat was processed and the origin of the meat. In the absence of a label, consumers may be assisted by their preferred butcher in determining the freshness of the meat (Becker et al. 2000).

For the purchase of fresh fruit and vegetables, modern retail outlets have the advantage of offering the produce in refrigerated display units. Furthermore, supermarkets and hypermarkets have the advantage of good retail procurement logistics, technology and inventory management (Reardon et al. 2003). As for the traditional market, goods are fresh during the early hours of business, but in a tropical climate like Malaysia, fruit and vegetables will quickly wither when being displayed in an open space without refrigeration. However, shoppers in Hong Kong interpret the lack of storage space and refrigeration as being positive, for fresh fruit and vegetables must be cleared daily, which further enhanced their freshness (Goldman et al. 1999). Consumers perceived that refrigerated products had been stored for a longer period, while fresh produce in the traditional markets was considered fresh and 'natural'. Focus group interviews in Malaysia indicated that consumers viewed fruit and vegetables in traditional markets as "more fresh" given that the produce was delivered directly 
from the wholesale market and farmers markets (Chamhuri and Batt 2009b). Furthermore, they perceived that the freshness of fresh fruit and vegetables could be maintained given that vendors constantly trimmed, sprayed, cleaned and sorted the produce.

\subsection{Competitive price}

Sinha and Banarjee (2004) and Goldman and Hino (2005) mentioned that price is a convincing tool which attracts consumers to purchase from a particular retail outlet. Ellaway and Macintyre (2000) revealed that price was an important consideration when purchasing food for consumers who belonged to the lower income group compared to more wealthy consumers. Generally, retail outlets which offer good quality products at a lower price will attract more consumers.

In the early stages of supermarket penetration, modern retail formats targeted high income earners and expatriates (Goldman and Hino 2005). As a result of this, supermarkets were perceived to be a place where wealthy people shopped. However, more recently, modern retail outlets have started to spread into small towns in rural areas to penetrate the fresh food markets for the poor (Reardon et al. 2003).

There is still much debate as to which retail store offers the lowest price for fresh food. Some research reveals that the price of food is much lower in supermarkets. McEachern and Seaman (2005) found that consumers who were more price-sensitive benefited from buying meats from supermarkets because of the cheaper price. In Malaysia, focus group discussants believed that modern retail outlets sold fresh fruit and vegetables at a much cheaper price compared to traditional retail outlets (Chamhuri and Batt 2009b).

Conversely, some research suggests that prices for fresh food are much cheaper in the traditional market. Goldman et al. (1999) demonstrated that in Hong Kong, fresh fruit and vegetables and other fresh food items such as meat and fish were perceived to be fresher and cheaper in most traditional markets. Berdegue et al. (2005) found that the price of fresh fruit and vegetables in modern retail outlets were $15 \%$ to $60 \%$ above traditional retailers. Hsu and Chang (2002) also found that the price of several meat cuts were cheaper in the traditional markets. 
The ability to bargain on price also differentiates consumers' purchasing experience in the traditional markets from modern retail outlets. Zinkhan et al. (1999) explained how bargaining is a cultural value which occurs in most traditional food markets in Brazil. Maruyama and Trung (2007) described bargaining as the 'art of shopping' and found that in Viet Nam, consumers who wanted to bargain were more likely to shop in traditional markets. Lui (2008) found that consumers who prefer to shop at wet markets mentioned that through bargaining, they managed to pay less than the actual price of the product and to receive additional products at no cost upon purchasing. Bargaining involves flexibility, which is impossible in supermarkets, for the price is normally fixed.

\subsection{Personalised service by traditional vendors}

One of the strategies small retailers employ to protect themselves from competition with modern retailers is to improve their level of service. Providing superior service to consumers in the form of providing better quality product, better knowledge about the product, and added services such as home delivery, replacement of defective products and credit facilities can enhance store loyalty (Sinha and Banarjee 2004). With repeat transactions and over time, personal relationships between retailers and consumers develop trust. Trust is perceived as an assurance given by vendors that the food is safe to eat and of high quality (Figuie et al. 2006).

Chamhuri and Batt (2009a) found that loyalty to the same vendor was another frequently cited variable which influenced the consumers' decision to purchase fresh meat. Consumers who were unaware of the different cuts or portions of meat could refer to vendors who were more knowledgeable. Additionally, these vendors provided personalised service for customers who required the meat to be chopped, sliced, skinned, de-boned and packed. Consumers valued friendly, trusted and knowledgeable vendors in traditional markets who were willing to provide assistance in helping them make their decision to purchase fresh meat. When purchasing from a trusted source, consumers became aware of the origin of the meat and most importantly, that the meat was Halal. As the majority of Malaysians are Muslim, it is important to purchase fresh meat from a trusted retail store that offers meat that is guaranteed Halal (Chamhuri and Batt 2009a).

Placencia (2004) described a corner shop as a place where people know one another. Customers who shop at corner shops engaged in social activities with the shop owners such as 
greeting and leaving-taking exchanges, how-are-you inquiries, and queries about health and family. The frequent interactions created rapport between both parties and as a result of this, the shopping experience became more pleasurable. The personalised services offered by traditional retailers are unique and cannot be easily replicated by modern retailers.

However, modern retailers recognise that consumers have a preference to shop at stores that provide them with knowledgeable, friendly and helpful assistants and they are trying to replicate the values practiced by traditional retailers. Arnold and Fernie (2000) found that hypermarket shoppers were often greeted by the same person at the entrance in order to create recognition and familiarity. This welcoming approach turned a large warehouse into a familiar neighbourhood shop. Alhemoud (2008) revealed that friendly staff and knowledgeable personnel were important for consumers when doing their grocery shopping at supermarkets.

\subsection{Convenience}

The concept of convenience has different meanings, depending on which retail outlet was chosen and the demographic profile of the consumers.

When shopping from a modern retail outlet, convenience means anything that saves or simplifies work and brings comfort to consumers. Trappey and Lai (1997) found that younger shoppers who are more occupied with work and family prefer to shop in supermarkets and hypermarkets, for these retail outlets better satisfy the needs of a faster-paced lifestyle. Geuens et al. (2003) described the convenience of shopping from modern retail outlets in terms of the facilities provided such as car parking, trolley's and baskets, proximity to other shops, extended trading hours, good presentation of products, signage, and the desired width and depth of the product range.

Bonne and Verbeke (2006) described convenience as one-stop shopping, where most consumers preferred to shop from supermarkets given that they could purchase everything they needed under one roof. According to Farhangmehr et al. (2001), since most goods such as fresh food, dry food and non-food items are available from modern retail outlets it is more practical to buy everything at the same time from the same place. Berdegue et al. (2005) found that some consumers were willing to pay a higher price to purchase their fresh produce 
in supermarkets rather than from traditional retailers because of convenience. Chamhuri and Batt (2009a) found that young consumers particularly disliked the idea of going to a butcher to purchase meat and then going to another store to purchase other groceries. However, older participants mentioned that they had been visiting the same local market, which they perceived to be more convenient for them, as it was close to where they lived. Since traditional markets seldom provide any parking place, shoppers who live nearby simply walked to the market.

\subsection{Clean environment}

The cleanliness of the store may influence the consumer's choice of retail store. A dirty retail outlet not only looks unattractive, but it may also suggest an unhygienic shopping environment. Birtwistle et al. (1996) mentioned that the cleanliness of the store was a natural concern for most food shoppers. Consumers were more confident with the quality and safety of the fresh food offered from a clean retail store.

Jabbar and Admassu (2009) revealed how cleanliness was measured by the hygiene of staff/butchers and premises. Their study demonstrated how respondents from higher income groups were more sensitive to cleanliness and perceived that better quality meat was sold from shops that were cleaner, where staff wore clean clothes and used clean equipment to process the meat. Cadilhon et al. (2006) suggested that offering a clean environment was becoming the norm for modern retailers to entice shoppers. Suryadarma et al. (2010) confirmed that the competitive advantage of modern supermarkets came from providing a clean environment and superior comfort for shoppers.

Cleanliness is seen as presenting a significant barrier for traditional retail outlets to compete with modern retailers. Generally, most traditional markets are described as wet, dirty and smelly, over-crowded, poorly ventilated and often inhabited by vermin (Goldman et al. 1999; Hsu and Chang 2002; Bougoure and Lee 2009). Berdegue et al. (2005) revealed that cleanliness of the store was important for most Central American consumers. Apparently, they assumed that the fresh produce being offered in a clean and tidy supermarket was safer to eat compared to that available from a dirty and disorganised market. Recognising the importance of providing a clean environment for shoppers, the Malaysian Ministry of Agriculture and Agro-Based Industry has begun to transform and modernise traditional 
markets by offering a more hygienic and conducive environment (Muda n.d.). Nevertheless, Suryadarma et al. (2010) mentioned that cleanliness was one of the least important variables for traditional retailers to attract more shoppers. Although supermarkets provide a good environment for shoppers (clean and air-conditioned), Maruyama and Trung (2007) found that consumers in Viet Nam still do most of their shopping for fresh meat in traditional markets. Similarly, Chamhuri and Batt (2009a) found that despite the unpleasant conditions, many consumers continue to purchase their fresh meat from traditional retail markets.

\section{Consumer segmentation}

In identifying the store choice attributes that influence the consumer's decision to purchase fresh food from their preferred retail outlet, related research suggests that it is important to segment consumers according to the importance they place on the various store choice criteria. Rigopoulou et al. (2008) highlighted the importance of customer segmentation as an approach to identify current and potential customers that are characterised by the homogeneity in their buying preferences, attitudes and behaviour.

In making their decision where to shop, consumers evaluate the importance of various retail store characteristics. However, according to Boedeker (1995) and Rigopoulou et al. (2008), the weightings attached to these retail store characteristics may differ between the consumers' socio-demographic variables, psychographic characteristics, product usage, the level of patronage and purchasing motives. Socio-demographic and psychographic variables are amongst the most popular bases for segmenting consumers in marketing research. Nevertheless, there is much debate as to which variables produce the best results to establish any linkage between different consumer groups and their choice of retail store. Carpenter and Moore (2006) linked demographic characteristics and desired store attributes in the US grocery market. However, Boedeker (1995) believes that psychographic measures greatly improve the picture when profiling shoppers.

\section{Methods}

After an initial exploratory investigation (Chamhuri and Batt 2009a; Chamhuri and Batt 2009b), a structured questionnaire was developed. The survey instrument for this research consisted of two questionnaires which sought to gather information regarding the store choice 
behaviour of the respondents and their perceptions of the quality of the respective commodity (fresh meat or fresh produce). Respondents were first asked several questions that were designed to identify the preferred place of purchase and the frequency of purchase.

Respondents were then asked to think about the criteria they most often used in their decision to purchase fresh meat (or fresh produce) from their most preferred retail outlet. An openended question allowed respondents to freely convey their views with regards to the topic of interest and to ensure that no major variables were excluded for the fixed response question sets that followed.

Respondents were asked to rate 35 criteria, which included the five groups of responses drawn from the literature and exploratory studies, and other criteria identified from the literature as having some influence on the choice of preferred retail outlet, on a scale from 1 to 6 , where 1 was "not at all important" and 6 was "very important".

The reality is however, that food shopping is more often than not a low involvement, habitual process (McKinna et al. 2007). It is unlikely therefore that respondents' will utilise all 35 variables when purchasing their fresh food from a retail store. Therefore, principal component analysis with varimax rotation and Kaiser normalisation was applied to group the variables into a smaller set of components.

Respondents were then presented with a number of statements which sought to measure the relationship between the respondents' perceptions of food quality and their preferred place of purchase. A six point scale was utilised where respondents were required to indicate the extent to which they agreed with each statement, where 1 was "I disagree a lot" and 6 was "I agree a lot". The statements included both the advantages and disadvantages of purchasing fresh food from either the traditional market or modern retail outlets. The statements: (1) compared the quality of the respective commodity available from both retail outlets (Zenk et al. 2005); (2) the ability to bargain on price (Maruyama and Trung 2007); (3) convenience (Farhangmehr et al. 2001; Abu and Roslin 2008); (4) cleanliness (Goldman et al. 1999; Bougoure and Lee 2009); (5) a comfortable environment (Goldman and Hino 2005; McEachern and Seaman 2005); (6) the consumers' relationship with vendors, and (7) their desire to purchase goods from knowledgeable vendors (Sinha and Banerjee 2004). 
With regard to the use of scales, there is considerable discussion about the appropriate use of either an odd or even-numbered scale. Coelho and Esteves (2007) argued that an evennumbered scale is the preferred choice of response alternatives in research associated with consumer attitudes and preferences. Respondents are perceived to have at least a slightly positive or slightly negative response rather than a neutral response. With an odd-numbered scale, Coelho and Esteves (2007) demonstrated that the middle-point was often used by respondents who preferred to reduce the response effort, which not unexpectedly, impacted adversely on the quality of the data. Mitchell (1999) revealed that Asian respondents preferred to use the middle of the scale when responding to surveys. Bishop (1987) suggested that in order to prevent respondents from choosing the middle-point, an even numbered scale should be employed. In the light of these findings, it was determined that a six-point scale was the most appropriate for this survey.

At the end of the questionnaire, socio-demographic information such as gender, age, ethnicity and occupation were collected.

In all, the sample consisted of 544 useable surveys (260 respondents from the fresh meat survey and 284 respondents from the fresh fruit and vegetable survey).

\section{Sampling technique and data collection}

The sampling technique used to select the respondents for this study was based on probability sampling (multi-stage sampling). This choice was made using a number of considerations: (a) extensive geographic areas need to be covered with minimum travelling costs; and (b) time constraints. To overcome these limitations, the researchers decided to select the respondents using a three-stage area sample.

The first stage involved a cluster sampling technique, which related to the area of the study. The Klang Valley was chosen as the research area for a number of reasons: (a) geographically, the Klang Valley lies between Selangor state and the Federal Territory which includes large cities like Kuala Lumpur (the national capital of Malaysia); (b) the availability of both modern retail outlets and traditional markets; and (c) it is a region which holds a good mixture of potential respondents with different levels of education, income distribution and 
ethnicity. Given that the Klang Valley region covers a vast area, seven principal cities were selected randomly for this survey.

In the second stage, the researchers made a list of modern retail outlets and traditional markets available in the cities that had been selected. In order to select the retail outlets for this study, the principal researchers had to consider two factors: (a) the time allocated for data collection (12 weeks); and (b) the period for the principal researcher and two research assistants to be stationed at a retail outlet (10am to $8 \mathrm{pm}$ daily for a period of one week). Subsequently, the principal researcher decided to spend six weeks at six selected modern retail outlets and another six weeks at six selected traditional retail outlets. These retail outlets were selected randomly.

The third step involved the selection of the respondents. The principal researcher and two research assistants were stationed at different entrances of the retail outlet. This was to ensure that most of the shoppers which visited the retail outlet at that particular time had some chance of being selected to participate in this study. To ensure randomness, every $7^{\text {th }}$ shopper passing by the researcher was intercepted and invited to particpate. Three screening questions were used to pre-qualify respondents: (a) nationality and place of residence, where expatriates and individuals not residing within the Klang Valley region were excluded from the survey; (b) respondents had to be personally involved in the decision to purchase either fresh meat or fresh fruit and vegetables for their household; and (c) each respondent was asked in advance to allocate 20 minutes of their time to complete the survey.

\section{Data analysis procedures}

Data was analysed using SPSS ver.16 through both univariate and multivariate analyses. The univariate analyses utilised in this study included descriptive analysis, one-way analysis of variance (ANOVA) and cross-tabulations. The multivariate techniques employed included exploratory factor analysis and cluster analysis.

Exploratory factor analysis was applied to the 35 criteria that had been shown from previous research to influence store choice. The objective was to reduce the dataset to a much smaller number of variables which were more manageable while retaining as much of the information as possible (Field 2009). In the first step, the correlation matrix was examined and the KMO 
and Bartletts's Test of Sphericity performed. Principal component analysis with varimax rotation was then employed to identify the factors. Only those factors with an Eigenvalue equal to or greater than 1.0 were considered, and only those variables with a factor loading of greater than 0.4 were retained. The reliability of each resultant factor was evaluated using Cronbach's alpha, where a value greater than 0.7 was considered acceptable (Field 2009).

Utilising 21 items which sought to measure the relationship between the respondents' perceptions of food quality and their preferred place of purchase, cluster analysis was then undertaken to identify groups of consumers who preferred to purchase their fresh meat or fresh fruit and vegetables from either a modern retail outlet, traditional markets or from both retail outlets. Having no knowledge of how many groups might be present in both data sets, the researcher employed a hierarchical cluster analysis in the first instance. Hierarchical cluster analysis suggested 2-5 cluster solutions for both data sets (fresh meat and fresh fruit and vegetables). In the second step, K-means clustering was utilised to verify the composition of the clusters according to the number of groups identified. The results from this procedure indicated that a two cluster solution was considered to be optimal for the fresh meat data set, whereas a three cluster solution was more appropriate for the fresh fruit and vegetable data set.

\section{Results}

\subsection{Summary of the respondents}

A non-parametric test was performed to compare the two data sets. No significant difference could be detected between the samples with regard to the socio-demographic variables. Theoretically, both data sets could therefore be combined and analysed together as one sample.

The sample for both surveys consisted of 554 respondents living in the Klang Valley region. The majority of respondents in this study were females, aged between 26 and 44 years old, most of who were married and were of Malay descent. Most respondents from both surveys possessed at least an undergraduate degree or a professional certificate. The majority of respondents were employed either within the private sector, the government sector or owned their own business. In terms of income, most respondents were from the middle income 
group, earning between RM2,000 to RM4,000 per month (approximately between USD650 to USD1,300).

In segmenting respondents according to their preferred retail store, cluster analysis identified two clusters for the fresh meat survey (Table 1).

Insert Table 1 about here

Cluster 1 described "modern retail shoppers". This group had a higher mean score on convenience and enjoyed shopping at modern retail outlets because products were clearly priced, the stored offered a greater variety of fresh food, and the fresh meat was displayed better. Respondents purchasing from modern retail outlets were less concerned about building any long term or enduring relationship with the vendors, and they generally disliked the idea of going to a traditional market merely to purchase fresh meat.

Conversely, Cluster 2 was described as the "traditional market shopper". This group believed that the meat was both fresher and cheaper in the traditional market. They were more loyal as they purchased fresh meat from the same vendors and were prepared to go out of their way to purchase fresh meat from traditional markets, even although they often purchased other household products from supermarkets. They also enjoyed the opportunity to bargain on price.

For the purchase of fresh fruit and vegetables, cluster analysis on this occasion, revealed that a three cluster solution was considered optimal.

Insert Table 2 about here

Cluster 1 described "modern retail shoppers". This group had a higher mean score on convenience. They most valued the diversity of the fresh food available in supermarkets, the products being clearly priced, the importance of extended trading hours and the provision of a comfortable environment for children.

Cluster 2 described "transient shoppers". Shoppers in this group were found not to be loyal to any retail outlet. They did not demonstrate any preference for a specific retail store at which 
to purchase these products suggesting that they would buy from whichever store was the most convenient whenever they needed to purchase fresh fruit and vegetables. The mean scores for this group were generally found to be in the mid-range of the scale.

Cluster 3 described "traditional market shoppers". This group scored highly on the opportunity to bargain on price and loyalty to the same vendor each time they purchased fresh fruit and vegetables. They believed that purchasing from a traditional market represented much better value, as good quality fresh produce was offered at a much lower price. Furthermore, retailers in the traditional markets were more knowledgeable about the products they sold.

Although socio-demographic variables have been widely used for the purpose of segmenting and profiling consumers, since the data is relatively easy to collect, measure and analyse, much of the literature has demonstrated that the socio-demographic variables are often ineffective in segmenting the behaviour of consumers. In classifying shoppers, Boedeker and Marjanen (1993) found that socio-demographic characteristics provided a very narrow perspective of consumer behaviour. According to Romano and Stefani (2006), using only demographic variables provided a very poor classification due to the weak correlation between the socio-demographic variables and the purchase decision. For both surveys, variables such as gender, age, marital status, highest level of education attained, race and income were found not to be significantly different between the clusters.

\subsection{Fresh meat survey}

Freshness $(85 \%)$ was the most frequently cited variable used by respondents in their decision to purchase fresh meat from a retail store (Table 3 ).

Insert Table 3 about here

The second group of variables which were most frequently cited included price (70\%) and cleanliness (54\%). Other variables which were most frequently cited included Halal (39\%), and variety $(25 \%)$. In terms of Halal, respondents were concerned primarily with the way in which the animal had been slaughtered. A retail outlet displaying a Halal certificate or logo was considered advantageous and could attract more customers to purchase from the shop. 
A variety of choice and the ability to choose many different portions enabled respondents to purchase the desired meat in the most appropriate form for the way in which they intended to cook and present the meat. For example, several respondents preferred to purchase a whole dressed chicken, while others preferred to purchase chicken proportions such as drumsticks, chicken wings, breast or thigh fillet.

Other variables respondents considered in their decision to purchase fresh meat were location (18\%), loyalty to the same vendors (17\%) and quality assurance (12\%). Location described the concept of convenience as respondents indicated that their preferred retail outlet was close to where they either lived or worked. Loyalty to the same vendor was a major consideration for several respondents on each occasion that they purchased fresh meat. Respondents were loyal to those vendors who were friendly, trustworthy and knowledgeable, and provided customers with the services they required.

When respondents were asked to indicate how important 35 attributes were in their decision to purchase, a total of sixteen variables were found to be equally important in the respondents' decision to purchase fresh meat from a retail store (Table 4).

Insert Table 4 about here

The variables included the physical attributes of the meat (freshness, clean and good quality produce); convenience (a wide range of fresh produce, I can self select, all product is clearly priced and labelled, a wide range of other fresh products, product is easily accessible, a quick fast checkout, a lot of sections and everything under one roof); value (value for money and competitive price), and the characteristics of the retail outlet (fresh produce is refrigerated and good customer service/friendly staff).

Those variables which were considered the least important included advertising for meat products on radio, television or newspapers, and several other features which described the retail outlet including credit facilities, shopping points/loyalty programs and the extent to which the retail outlet catered for kids. These characteristics were found only among the modern retail formats. 
Principal component analysis revealed five constructs which collectively explained $63.5 \%$ of the variance (Table 5).

Insert Table 5 about here

Factor One, with an Eigenvalue of 6.58 was comprised of seven items. This factor was labelled as "perceived risk", for these items collectively explained the perceived risk which operated at both the product level and the store level. Consumers could minimise temporal or time risks if products were easily accessible, checkouts were operating quickly and efficiently, and the stores were open at a time that was convenient to the shopper. The risks associated with the product itself could be lessened when the product was clearly labelled and the origin of the product was clearly displayed. Loyalty is itself a risk mitigation mechanism. With a Cronbach's alpha of 0.86 , this construct was very reliable. With a mean of 5.2 , this factor was found to be the second most important in the respondents' decision to purchase fresh meat from a retail store.

Factor Two had an Eigenvalue of 2.20 and a Cronbach's alpha of 0.84. The six items that loaded onto this factor clearly described the "characteristics of a modern retail outlet" where the premises were generally air-conditioned, which provided a more comfortable environment for the shoppers and their children. Consumers could also benefit from the facilities provided by most modern retail outlets including credit card facilities and the use of trolleys and baskets for shopping. Promotional items such as shopping points/loyalty programs and advertised goods were additional features of modern retailing. However, this factor was the least important criteria in the respondents' decision to purchase fresh meat from a retail store.

Factor Three, with an Eigenvalue of 1.46 included three items: good quality produce, freshness and cleanliness. This factor was labelled as "quality". With a Cronbach's alpha of 0.74 , not only was the construct considered reliable, but it was also the singly most important construct in the respondents' decision to purchase fresh meat from a retail store.

Factor Four, with an Eigenvalue of 1.35 was also comprised of three items. Factor Four described the concept of "convenience". When purchasing fresh food, consumers may consider going to a particular retail outlet where all the households' consumables are available under one roof, the location of the store is close to their house or workplace, and 
there is ample car parking available. As the concept of convenience facilitated the shopper's purchasing experience, this factor was the second most important construct respondents considered in their decision to purchase fresh meat from a retail outlet. However, the Cronbach's alpha for this factor was only 0.66 .

Factor Five, with an Eigenvalue of 1.11 captured only one item which described "price". Respondents perceived price differently, depending on the place of purchase. For example, the price of fresh meat in a traditional market is not commonly fixed and thus consumers have an opportunity to bargain. Conversely, in modern retail outlets, the prices are fixed. Nevertheless, competition between the retail chains is often based on offering the lowest price which in the end, benefits the consumer. This was the third most important factor respondents considered in their decision to purchase fresh meat from a retail outlet.

An Independent samples t-test revealed that there were significant differences for Factor Two, Factor Four and Factor Five between the clusters (Table 6).

Insert Table 6 about here

Factor Two and Factor Four were found to be significantly more important for modern retail shoppers who preferred a clean and comfortable place to shop and who sought greater convenience.

Factor Five on the other hand was found to be significantly more important for respondents in Cluster 2. Traditional market shoppers tended to be more price conscious and to enjoy the opportunity to bargain on price with vendors that they trusted and had a good relationship with.

\subsection{Fresh fruit and vegetables survey}

In making their decision to purchase fresh fruit and vegetables from a retail store, most respondents (83\%) mentioned freshness, followed by price (74\%) (Table 7).

Insert Table 7 about here 
Other variables most frequently cited included variety (27\%), quality (26\%) and cleanliness (23\%). The concept of convenience was cited by $20 \%$ of respondents who considered proximity to their place of residence. Another group of variables most often cited by respondents included a comfortable environment (13\%) and easy access to the retail outlet $(8 \%)$.

When respondents were asked to indicate how important 35 items were in their decision to purchase fresh fruit and vegetables, a total of sixteen variables were found to be equally important in influencing the respondents' decision to purchase from a retail store (Table 8).

Insert Table 8 about here

The sixteen variables were grouped under four themes; the physical attributes of the fresh fruit and vegetables (freshness, clean and good quality produce); convenience (a wide range of fresh produce, I can self select, a wide range of other fresh products, all product is clearly priced and labelled, product is easily accessible, a quick fast checkout, a lot of sections and everything under one roof); value (value for money and competitive price), and the characteristics of the retail outlet (good customer service/friendly staff and fresh produce is refrigerated).

Those variables which were of least importance to respondents when purchasing fresh fruit and vegetables were credit facilities, advertising in the print or electronic media, catering for the kids and shopping points/loyalty programs.

Principal component analysis revealed four factors which explained $64.6 \%$ of the variance observed in the respondents' decision to purchase fresh fruit and vegetables from a retail store (Table 9).

Insert Table 9 about here

Factor One, with an Eigenvalue of 7.29, captured seven items and accounted for $24.7 \%$ of the variance. Collectively, these items were described as "perceived risks". In order to minimise risk, consumers preferred to select from a wide range of fresh produce, to have access to a wide range of other fresh produce and for the product to be easily accessible within their 
preferred retail outlet. Consumers also wished to reduce the financial risk. This included product that was clearly priced and clearly labelled, the availability of good quality produce and the opportunity to self select the products. The Cronbach's alpha for this factor was 0.91 , indicative of a very high reliability. In making the decision to purchase fresh fruit and vegetables from a retail outlet, this factor was ranked as the most important criteria by respondents.

Factor Two captured six items and had an Eigenvalue of 2.55. The Cronbach's alpha for this factor was 0.85 . The six items described the "attributes of modern retail outlets" which comprised several promotional items (advertising in the media, shopping points/loyalty programs), a comfortable shopping atmosphere for the whole family, and return and credit facilities in order to attract more consumers to shop there. This factor however, was the least important construct in the respondents' decision to buy fresh fruit and vegetables.

Factor Three, with an Eigenvalue of 1.31, had three items and accounted for $11.2 \%$ of the variance. The Cronbach's alpha for this factor was 0.71. Items in Factor Three described the "convenience factors" consumers search for when doing their shopping. It was comprised of items such as the accessibility of easy parking, the availability of most grocery products in the same shopping precinct, and the location of the retail outlet.

Factor Four, with an Eigenvalue of 1.11 captured three items and accounted for $9.8 \%$ of the variance. The three items described the "value" which comprised competitive price, value for money, and the opportunity to bargain on price. The Cronbach's alpha for this factor was 0.64. Factor Three and Factor Four were considered equally important by respondents and were the second most important construct in making their decision to purchase fresh fruit and vegetables from a retail outlet.

An analysis of variance (ANOVA) demonstrated that there were significant differences for all four factors between the three clusters (Table 10).

Insert Table 10 about here 
Factor One was found to be significantly more important for modern retail and traditional market shoppers. Both shoppers perceived that their preferred retail outlet could offer better quality fresh fruit and vegetables with minimal risks involved.

Factors Two (modern retail outlet), Three (convenience) and Four (value) were also found to be equally important for both modern retail and traditional market shoppers. Both clusters perceived that their preferred retail outlet was more convenient and offered the best value when purchasing fresh fruit and vegetables.

Even although the members of Cluster Three preferred to purchase the majority of their fresh fruit and vegetables from the traditional market, that did not preclude them from recognising the superior features of the modern retail shopping environment, nor did it preclude them from purchasing other household items from modern retail outlets. The implication here is that the purchase of fresh fruit and vegetables involves a much lower level of involvment than the purchase of fresh meat. This is reinforced by the emergence of a third cluster, the transient shopper, who had no preference for a specific retail outlet.

\section{Discussion}

In segmenting consumers according to the type of fresh food purchased and their preferred retail store, cluster analysis identified two clusters (modern retail shoppers and traditional market shoppers) for the fresh meat survey, and three clusters (modern retail shoppers, transient shoppers and traditional market shoppers) for the fresh fruit and vegetable survey. Although the clusters were labelled using similar terms, several similarities and differences were identified in the respective clusters for each fresh food item.

The findings indicate that with respect to the purchase of fresh meat, respondents were more selective when it came to where they preferred to purchase their meat. Consumers' level of involvement was much higher for the purchase of fresh meat compared to fresh fruit and vegetables. According to McCarthy and O'Reilly (1999), meat is a product that poses a higher level of risk to consumers, both financially, as it is perceived to be more expensive than fresh fruit and vegetables, and from a food safety perspective. However, the risk can be lessened depending on the type and amount of information provided. 
As the majority of consumers in Malaysia are Muslim (60\%) (Abu and Roslin 2008), in the absence of any legitimate third party certification, the personal trust developed between customers and vendors was important in determining the Halal status of fresh meat. This finding was similar to previous research by Bonne and Verbeke (2006) and Wan Omar et al. (2008). Trust was highly associated with the place of purchase for meat products, as most Muslims prefer to purchase fresh meat from an Islamic butcher who operates in a traditional market. Consumers place much value on being served by butchers of the same ethic race and religion (Goldman and Hino 2005; Bonne and Verbeke 2006).

However, the findings were somewhat different when it came to the purchase of fresh fruit and vegetables by Malaysian respondents. Transient shoppers were found in the fresh fruit and vegetables survey but not in the fresh meat survey. Transient shoppers did not demonstrate any preference for a particular retail store when purchasing fresh fruit and vegetables. These respondents were more flexible in choosing the place to purchase fresh produce. Given that the purchase of fresh produce is often seen as a routine task, these shoppers will visit which ever retail store is perceived to be the most convenient for them at that time.

\subsection{Conclusions and implications}

This study has provided valuable information for retailers to understand the behaviour of Malaysian consumers when purchasing fresh meat and fresh fruit and vegetables. Retailers from both markets can capitalise on the store choice attributes which influence consumer's purchasing behaviour.

Modern retail shoppers for both fresh meat and fresh produce valued the convenience factors and the enjoyment of shopping from modern retail stores due to the availability of a wider range of fresh food, products that were clearly priced and better displayed. Linking the concept of convenience with supermarkets was mentioned by Farhangmehr et al. (2001), Shamsudin and Selamat (2005), Abu and Roslin (2008) and Ahmed (2008).

Given that supermarkets and hypermarkets are able to offer many products to customers, this type of retail store is preferred due to its convenience (time) and practicality (Farhangmehr et al. 2001). Shamsudin and Selamat (2005) believe that the aspect of convenience and the 
provision of a comfortable shopping environment are among the competitive advantages modern retail outlets offer their shoppers. Ahmed (2008) found that the motive for consumers to shop at supermarkets was because everything was under one roof. Abu and Roslin (2008) described grocery shopping as a family outing for many Malaysians. For this reason, Malaysian consumers do their grocery shopping in modern retail stores, so that, at the same time, they can dine with the whole family, or accomplish other activities.

In terms of the ability of modern retail outlets to offer a wider range of food, Shamsudin and Selamat (2005) found that many Malaysian shoppers prefer to purchase their food products from supermarkets and hypermarkets because of the wide range of food from domestic and imported sources. Furthermore, shoppers who visit modern retail outlets are able to purchase a greater variety of processed food products (Hsu and Chang 2002).

Better product presentation may also attract shoppers to purchase their fresh food from supermarkets and hypermarkets. Bougoure and Lee (2009) found that consumers in Hong Kong described supermarkets as being superior to wet markets in their tangible offerings, which included how products were presented.

With regard to the purchase of fresh fruit and vegetables, respondents emphasised the benefits of visiting modern retail outlets, given that supermarkets and hypermarkets have longer operating hours compared to traditional markets. In Hong Kong for example, Bougoure and Lee (2009) indicated that the opening hours of most wet markets are governed by the government, which some describe as customer unfriendly, given that the trading hours do not cater to the needs of all consumers. Although extended trading hours are preferred by consumers, such may appeal only to a certain segment of consumers. Richbell and Kite (2007) revealed that younger shoppers benefited the most from extended shopping hours.

In the traditional market, for both fresh meat and fresh produce, both groups of shoppers were loyal to the same vendors each time they purchased fresh food from the traditional market. In purchasing fresh meat, to ensure that the meat was safe and Halal, Grunert et al. (2004) found that consumers prefer to entrust their purchase to a butcher who is an expert in their field. In addition to this, the personalised services offered by the butcher such as cleaning the chicken or cutting the meat according to the consumers' preferences encouraged loyalty. Farhangmehr 
et al. (2001) demonstrated the linkage between loyalty and store patronage, describing it as a relationship between the consumer and an entity (service or vendor).

As a result of having a good relationship with the vendors, shoppers purchasing fresh meat and fresh fruit and vegetables were able to bargain on price. The findings of this study concur with Maruyama and Trung (2007) and Lui (2008), who revealed that bargaining on price was more likely to happen in traditional markets instead of modern retail outlets. Traditional retailers demonstrated that through bargaining, compromises could be made as long as it did not result in a huge loss from the transaction. Bargaining had symbolic value in reinforcing the tie between consumers and the retailer. However, bargaining requires skills, given that the better the shopper is at bargaining, the cheaper the price will become (Maruyama and Trung 2007; Huong n.d.). Maruyama and Trung (2007) found that the ability to bargain was related to the gender of the shopper. Given that men do not like bargaining as much as women, males are more likely to shop from supermarkets. In a similar study, Huong (n.d.) found that supermarkets attracted more male shoppers because they could avoid bargaining. Maruyama and Trung (2007) suggest that shoppers who do most of their shopping from supermarkets do not consider bargaining to be useful. For them, obtaining products at a cheaper price was less important in their decision to purchase. When shopping at a modern retail store, they searched for products that were safer and of better quality.

Traditional shoppers for fresh meat believed that the fresh meat was fresher in the traditional markets. As a result, they would purposely visit the traditional market to purchase their fresh meat, even although they purchased other household products from supermarkets or hypermarkets. Goldman et al. (1999) report that shoppers often split their food purchases according to food items. Traditional markets were still the preferred place to purchase fresh food items, while modern retail outlets were the place to purchase other dry, frozen and prepackaged food items.

The emergence of modern retail shoppers suggest that supermarkets and hypermarkets have expanded to serve a larger segment of the market, due to factors such as preference for convenience, extended trading hours, freshness and a wide variety of clearly priced food items in a comfortable environment. At the same time, traditional markets continue to service their loyal shoppers due to the friendly service provided by vendors, the ability to bargain on price 
and the perceived freshness of the food offered. Traditional markets will continue to survive for some time as many consumers still appreciate the benefits that they bestow.

Nevertheless, there is a tendency for more affluent food shoppers to change their shopping habits and to shift towards the modern retail outlets. Competition will intensify for traders, vendors and hawkers in the traditional market to remain in business. If they are to survive, traditional retailers must find an additional means of differentiating their product offer to encourage shoppers to continue purchasing from them. One of the greatest challenges for traditional retailers is to provide safe and high-value fresh food to their consumers, due to the lack of storage space, a clean display area, and poor transportation from suppliers to retailers. Although safety and quality requirements impose higher costs, traditional retailers should endeavour to improve their standards to improve their image, as well as to gain the consumers' confidence. As highlighted by Reardon and Gulati (2008), it is important for government to assist small retailers to meet the challenges and requirements of the modern food marketing system.

Even although traditional markets provide a less pleasant environment, interpersonal relationships thrive and the community is brought closer together. Trappey and Lai (1997) reveal how supermarkets in Taiwan have adopted store layouts which resemble traditional markets to encourage greater social interaction between their staff and customers. Therefore, modern retailers should emphasize the importance of providing superior service to consumers as a way of attracting more shoppers to purchase from supermarkets and hypermarkets, and to enhance store loyalty.

\section{Limitations}

Several limitations were identified at different stages of this study which may impact on the analysis of data and its findings. Some limitations were created intentionally to establish some research boundaries, while other limitations are identified as opportunities for future research.

In order to set a research boundary, this study was limited to Malaysian consumers residing in the Klang Valley only. As a result of this, the respondents who participated in this study may not be representative for the whole of Malaysia. The behaviour of respondents from urban areas such as the Klang Valley may differ from the behaviour of respondents in rural areas 
and from those respondents in East Malaysia. At present, only those respondents living in the major metropolitan centres have access to modern retail outlets. Consequently, consumers in the rural areas may be dependent on the traditional markets for procuring their fresh food.

Due to limitations in financing this research, as well as time constraints, the sample size for this study was small compared to most other studies. Despite the small sample size, this study was able to demonstrate different preferences towards a particular retail store. Given that this study is among the first to examine the differences in store choice behaviour for fresh meat and fresh fruit and vegetables in Malaysia, the sample size for this study was sufficient. The findings of this research add to the current literature and provide suggestions for retailers, local vendors and various agencies involved in the marketing and distribution of fresh food in Malaysia.

Despite the limitations highlighted, there are several areas that are seen as fertile areas for future research to expand and enhance current knowledge.

Given that this study was limited to a fixed geographic area, the Central Region of Malaysia, subsequent research could draw a sample from other regions such as the Northern Region, East Coast Region, Southern Region and East Malaysia. Conducting the study in different geographic localities will be necessary to capture the impact of different ethnic groups and the different levels of economic development in Malaysia. Furthermore, additional studies will be useful to validate the findings drawn from this study.

It is suggested that future researchers draw a larger sample size to capture the diversity in socio-demographic variables. While the socio-demographic variables had little influence on the behaviour of consumers in this study, much of the literature reports that sociodemographic variables such as age, gender, level of income and educational background may affect consumers store choice behaviour. For instance, the sample for this study was comprised predominantly of younger women. The more elderly in the population may have very different views on store choice and the criteria they consider in their decision to purchase fresh food from a retail store.

Finally, this study could be further expanded to examine the impact of the modernisation of the food retail industry on traditional retailers in Malaysia. Factors such as food safety, 
everything under one roof, convenience and cleanliness were among the criteria identified in this study which attract consumers to supermarkets and hypermarkets. Although factors such as the guarantee that the food purchased is Halal and the relationship established with the same butcher may prevent customers from changing to different retail outlets, retailers in the traditional markets may be adversely affected by other changes that are occurring in the food retail industry.

\section{References}

Abu, N.K. \& Roslin, R.M. 2008. Exploring Halal service quality dimension in the Malaysian grocery retail sector. International Journal of Interdisciplinary Social Sciences, 3(2), 33-40.

Ahmed, A. 2008. Marketing of halal meat in the United Kingdom: Supermarkets versus local shops. British Food Journal, 110(7), 655-670.

Alhemoud, A.M. 2008. Shopping behaviour of supermarket consumers in Kuwait. Journal of Business and Economics Research, 6(3), 47-58.

Arnold, S.J. \& Fernie, J. 2000. Wal-Mart in Europe: prospects for the UK. International Marketing Review, 17(4/5), 416-432.

Becker, T., Benner, E. \& Glitsch, K. 2000. Consumer perception of fresh meat quality in Germany. British Food Journal, 102(3), 246-266.

Beharrell, B. \& Denison, T.J. 1995. Involvement in a routine food shopping context. British Food Journal, 97(4), 24-29.

Berdegue, J.A., Balsevich, F., Flores, L. \& Reardon, T. 2005. Central American supermarkets' private standards of quality and safety in procurement of fresh fruits and vegetables. Food Policy, 30(3), 254-269.

Birtwistle, G., Clarke, I. \& Freathy, P. 1996. Consumer versus retailer perceptions of store positioning in the UK fashion sector. Working Paper No. 9602, The Institute for Retail Studies, University of Stirling.

Bishop, G.F. 1987. Experiments with the middle response alternative in survey questions. Public Opinion Quarterly, 51(2), 220-232.

Boedeker, M. 1995. New-type and traditional shoppers: A comparison of two major consumer groups. International Journal of Retail \& Distribution Management, 23, 17-26.

Boedeker, M., \& Marjanen, H. 1993. Choice orientation types and their shopping trips to the city centre vs. to an edge-of-town retail park. Paper presented at the $7^{\text {th }}$ International Conference on Research in the Distributive Trades, Institute for Retail Studies, University of Stirling, Scotland.

Bonne, K. \& Verbeke, W. 2006. Muslim consumer's motivations towards meat consumption in Belgium: qualitative exploratory insights from means-end chain analysis. Anthropology of Food. Retrieved from http://aof.revues.org/index90.html

Bougoure, U. \& Lee, B. 2009. Service quality in Hong Kong: Wet markets vs supermarkets. British Food Journal, 111(1), 70-79.

Cadilhon, J.J., Moustier, P., Poole, N.D., Tam, P.T.G. \& Fearne, A.P. 2006. Traditional vs. modern food systems? Insights from vegetable supply chains to Ho Chi Minh (Viet Nam). Development Policy Review, 24(1), 31-49.

Carpenter, J.M. \& Moore, M. 2006. Consumer demographics, store attributes, and retail format choice in the US grocery market. International Journal of Retail \& Distribution Management, 34(6), 434-452. 
Chamhuri, N. \& Batt, P.J. 2009a. Factors influencing consumers' choice of retail stores for fresh meat in Malaysia. Paper presented at the $19^{\text {th }}$ Annual World Food and Agribusiness Forum and Symposium, Budapest, Hungary, 20-23 ${ }^{\text {rd }}$ June 2009.

Chamhuri, N. \& Batt, P.J. 2009b. Consumer choice of retail outlet: Focus group interviews in Malaysia. Acta Horticulturae, 831, 237-246.

Cheeseman, N. \& Wilkinson, M. 1995. Food retailing in Taiwan: Developments, future directions and opportunities. Agribusiness Marketing Series, QI 95029. Queensland, Australia: Queensland Department of Primary Industries.

Coelho, P.S. \& Esteves, S.P. 2007. The choice between a 5-point and a 10-point scale in the framework of customer satisfaction measurement. International Journal of Market Research, 49(3), 313-345.

Ellaway, A., \& Macintyre, S. 2000. Shopping for food in socially contrasting localities. British Food Journal, 102(1), 52-59.

Engel, J.F., Blackwell, R.D. \& Miniard, P.W. 1995. Consumer Behaviour, Eight Edition, Dryden Press, Orlando.

Euromonitor. 1986. The changing face of grocery retailing. London.

Farhangmehr, M., Marques, S., \& Silva, J. 2001. Hypermarkets versus traditional retail stores - consumers' and retailers perspectives in Braga: A case study. Journal of Retailing and Consumer Services, 8(4), 189-198.

Field, A. 2009. Discovering statistics using SPSS ( $3^{\text {rd }}$ ed.). London: Sage.

Figuie, M., Tam, P.T.G. \& Truyen, N.D. 2006. Poor consumer access to supermarkets in Hanoi. In P. Moustier, D.T. Anh, H.B. An, V.T. Binh, M. Figuie, N.T.T. Loc \& P.T.G. Tam (Eds), Supermarkets and the poor in Viet Nam. Hanoi: CIRAD/ADB.

Geuens, M., Brengman, M. \& Jeger, R. 2003. Food retailing, now and in the future. A consumer perspective. Journal of Retailing and Consumer Services, 10(4), 241-251.

Goldman, A. \& Hino, H. 2005. Supermarkets vs. traditional retail stores: diagnosing the barriers to supermarkets' market share growth in an ethnic minority community. Journal of Retailing and Consumer Services, 12(4), 273-284.

Goldman, A., Krider, R. \& Ramaswami, S. 1999. The persistent competitive advantage of traditional food retailers in Asia: Wet market's continued dominance in Hong Kong. Journal of Macromarketing, 19(2), 126-139.

Grunert, K.G., Bredahl, L. \& Brunso, K. 2004. Consumer perception of meat quality and implications for product development in the meat sector - a review. Meat Science, 66, 259272.

Harris, S.M. 2007 Does sustainability sell? Marke responses to sustainable certification. Management of Environmental Quality: an International Journal, 18(1), 50-60.

Hsu, J.L. \& Chang, W.H. 2002 Market segmentation of fresh meat shoppers in Taiwan. International Review of Retail, Distribution and Consumer Research, 12(4), 423-436.

Humphrey, J. 2007. The supermarket revolution in developing countries: tidal wave or tough competitive struggle. Journal of Economic Geography, 7(4), 433-450.

Huong, B.T. n.d. From traditional to modern market: The dynamics of Vietnamese consumer behaviour and its implications on the development strategy of modern retailers. Retrieved November 19, 2009, from http://www.cfvg.org/files/Ouverture_Internationale_11.pdf\#page=49

Jabbar, M.A. \& Admassu, S.A. 2009. Assessing consumer preferences for quality and safety attributes of food in the absence of official standards: the case of beef in Ethiopia. Paper presented at the International Association of Agricultural Economists conference, Beijing, China, 16-22 August 2009.

Lui, S. 2008. An ethnographic comparison of wet markets and supermarkets in Hong Kong. The Hong Kong Anthropologist, 2, 1-52. 
Maruyama, M. \& Trung, L. V. 2007. Traditional bazaar or supermarkets: A probit analysis of affluent consumer perceptions in Hanoi. International Review of Retail, Distribution and Consumer Research, 17(3), 233-252.

McCarthy, M. \& O'Reilly, S. 1999. Beef purchase behaviour: Consumer use of quality cues and risk reduction strategies - findings from focus group discussions. Discussion Paper Series, Department of Food Business and Development, University College Cork, Ireland.

McEachern, M.G. \& Seaman, C. 2005. Consumer perceptions of meat production: Enhancing the competitiveness of British agriculture by understanding communication with the consumer. British Food Journal, 107(8), 572-593.

McKinna, D. 2007. Marketing plan for the Tasmanian vegetable industry. Department of Primary Industries Tasmania.

Mitchell, J. 1999. Reaching across borders. Marketing News, 33. American Marketing Association, Chicago, IL.

Muda, N.H. 2010. Wet market still relevant to consumers. Bernama. Retrieved January 20, 2010, from http://web10.bernama.com/fama/news.php?lang=\&id=270419

Placencia, M.E. 2004. Rapport-building activities in corner shop interactions. Journal of Sociolinguistics, 8(2), 215-245.

Reardon, T., Timmer, C.P., Barrett, C.B. \& Berdegue, J. 2003. The rise of supermarkets in Africa, Asia, and Latin America. American Journal of Agricultural Economics, 85(5), 11401146.

Reardon, T., Timmer, C.P. \& Minten, B. 2010. Supermarket revolution in Asia and emerging development strategies to include small farmers. Proceedings of the National Academy of Sciences of the USA (PNAS). December 6.

Richbell, S. \& Kite, V. 2007. Night shoppers in the "open 24 hours" supermarket: a profile. International Journal of Retail \& Distribution Management, 35(1), 54-68.

Rigopoulou, I.D., Tsiotsou, R.H. \& Kehagias, J.D. 2008. Shopping orientation-defined segments based on store-choice criteria and satisfaction: An empirical investigation. Journal of Marketing Management, 24(9-10), 979-995.

Romano, D., \& Stefani, G. 2006. The trust project: Summary of main findings. In D. Romano \& G. Stefani (Eds), How safe is eating chicken? A study on the impact of trust and food risk communication on consumer behaviour in the European Union (Italy: Firenze University Press, 143-150.

Roslin, R.M. \& Melewar, T.C. 2008. Hypermarkets and the Small Retailers in Malaysia: Exploring Retailers' Competitive Abilities. Journal of Asia-Pacific Business, 9(4), 329-343.

Shamsudin, M.N. \& Selamat, J. 2005. Changing retail food sector in Malaysia. PECC Pacific Food System Outlook 2005-06 Annual Meeting. Kunming, China 11-13 May.

Sinha, P.K. \& Banarjee, A. 2004. Store choice behaviour in an evolving market. International Journal of Retail and Distribution Management, 32(10), 482-494.

Solgaard, H.S. \& Hansen, T. 2003. A hierarchical Bayes model of choice between supermarket formats. Journal of Retailing and Consumer Services, 10(3), 169-180.

Suryadarma, D., Paesoro, A., Akhmadi, S.B., Rosfadhila, M. \& Suryahadi, A. 2010. Traditional food traders in developing countries and competition from supermarkets: Evidence from Indonesia. Food Policy, 35(1), 79-86.

Trappey, C. \& Lai, M.K. 1997. Differences in factors attracting consumers to Taiwan's supermarkets and traditional wet markets. The Journal of Family and Economics Issues, 18(2), 211-224.

Verbeke, W. \& Vackier, I. 2004. Profile and effects of consumer involvement in fresh meat. Meat Science, 67, 159-168. 
Wan Omar, W.M., Muhammad, M.Z. \& Che Omar, A. 2008. An analysis of the Muslim consumers' attitudes towards Halal food products in Kelantan. In: N.K. Nik Muhamad, Y.H. Bidin, W.H. Wan Hasan, A. Ariffin, M. Idrus, M. Hassan, M.I. Mohd Salleh, N.S. Zainal Abidin, N.R. Alias, R. Ishak, W.A. Wan Hassan \& W.N. Wan Mohamed (Eds), Proceedings of ECER Regional Conference: Thrusting Islam, Knowledge and Professionalism in ECER Development UTM: UPENA, 165-177.

Wee, C.H. 1993. Shopping behaviour of different age groups: how different are they? Proceedings of the World Marketing Congress, Vol. VI, 485-490.

Wong, L.C.Y. 2007. Development of Malaysia's agricultural sector: agriculture as an engine of growth? Proceedings of ISEAS Conference on the Malaysian Economy: Development and Challenges, Singapore, 25-26 January 2007.

Yiridoe, E.K., Bonti-Ankomah, S. \& Martin, R.C. 2005. Comparison of consumer perceptions and preferences towards organic versus conventionally produced food: a review and update of the literature. Renewable Agriculture and Food Systems, 20(4), 193-205.

Zenk, S.N., Schulz, A.J., Hollisneely, T., Campbell, R.T., Holmes, N., Watkins, G. \& Odomsyoung, A. 2005. Fruit and vegetable intake in African Americans: Income and store characteristics. American Journal of Preventive Medicine, 29(1), 1-9.

Zinkhan, G.M., De Fontenelle, S. \& Balazs, A.L. 1999. The structure of Sao Paulo street markets: evolving patterns of real institutions. The Journal of Consumer Affairs, 33(1), 3-26. 
Table 1: Respondents level of agreement/disagreement with each of these statements according to cluster

\begin{tabular}{|c|c|c|c|c|c|}
\hline & \multicolumn{2}{|c|}{ Cluster 1} & \multicolumn{2}{|c|}{ Cluster 2} & \multirow[t]{2}{*}{$\overline{\mathbf{P}}$} \\
\hline & Mean & SD & Mean & SD & \\
\hline $\begin{array}{l}\text { The quality of the fresh meat available is better in } \\
\text { supermarkets }\end{array}$ & 4.82 & 0.90 & 3.62 & 1.26 & 0.000 \\
\hline $\begin{array}{l}\text { Supermarkets operate everyday while traditional } \\
\text { markets operate only on certain days of the week }\end{array}$ & 5.02 & 1.28 & 4.27 & 1.53 & 0.000 \\
\hline Consumers can bargain on price in wet markets & 4.55 & 1.36 & 5.29 & 1.02 & 0.000 \\
\hline $\begin{array}{l}\text { Its more convenient to shop in supermarkets } \\
\text { because I can buy all my groceries at the same } \\
\text { time }\end{array}$ & 5.59 & 0.64 & 4.95 & 1.07 & 0.000 \\
\hline $\begin{array}{l}\text { I often meet my friends when I shop at traditional } \\
\text { markets }\end{array}$ & 2.84 & 1.25 & 3.79 & 1.45 & 0.000 \\
\hline Supermarkets offer a wider range of fresh food & 5.33 & 0.83 & 4.19 & 1.28 & 0.000 \\
\hline $\begin{array}{l}\text { At traditional markets, the vendors remember my } \\
\text { name }\end{array}$ & 3.34 & 1.56 & 4.24 & 1.44 & 0.000 \\
\hline $\begin{array}{l}\text { I cannot buy the other household items I need if I } \\
\text { shop at traditional markets }\end{array}$ & 4.77 & 1.27 & 3.91 & 1.44 & 0.000 \\
\hline $\begin{array}{l}\text { I go to supermarkets because of the shopping } \\
\text { points I get }\end{array}$ & 3.91 & 1.58 & 3.47 & 1.44 & 0.027 \\
\hline $\begin{array}{l}\text { The children feel comfortable when I shop at } \\
\text { supermarkets }\end{array}$ & 5.17 & 0.95 & 4.44 & 1.29 & 0.000 \\
\hline $\begin{array}{l}\text { Traditional markets seldom have a good or clean } \\
\text { environment }\end{array}$ & 4.96 & 1.14 & 4.07 & 1.12 & 0.000 \\
\hline $\begin{array}{l}\text { Supermarkets offer better customer service than } \\
\text { the traditional markets }\end{array}$ & 4.96 & 0.93 & 4.26 & 1.21 & 0.000 \\
\hline $\begin{array}{l}\text { I can return easily goods if I'm not satisfied when I } \\
\text { buy them from traditional markets }\end{array}$ & 3.74 & 1.33 & 4.23 & 1.22 & 0.004 \\
\hline $\begin{array}{l}\text { I buy my other household goods from } \\
\text { supermarkets but I buy my chicken and beef } \\
\text { supplies from traditional markets }\end{array}$ & 3.19 & 1.29 & 5.30 & 0.99 & 0.000 \\
\hline $\begin{array}{l}\text { Traditional markets offer better quality meat at a } \\
\text { much cheaper price }\end{array}$ & 3.54 & 1.18 & 5.01 & 1.067 & 0.000 \\
\hline $\begin{array}{l}\text { I can return easily goods that I'm not satisfied with } \\
\text { after purchasing it from supermarkets }\end{array}$ & 4.33 & 1.36 & 3.85 & 1.45 & 0.011 \\
\hline Fresh meat is displayed better in supermarkets & 5.19 & 0.86 & 4.64 & 1.02 & 0.000 \\
\hline Chicken and beef are fresher in traditional markets & 4.14 & 1.19 & 5.51 & 0.79 & 0.000 \\
\hline $\begin{array}{l}\text { I prefer to buy my fresh meat from the same } \\
\text { vendor in the traditional markets }\end{array}$ & 3.96 & 1.25 & 5.36 & 0.84 & 0.000 \\
\hline Products in the supermarkets is clearly priced & 5.48 & 0.65 & 5.23 & 0.89 & 0.014 \\
\hline $\begin{array}{l}\text { Retailers in the traditional market are more } \\
\text { knowledgeable about the products they sell }\end{array}$ & 4.22 & 1.25 & 5.23 & 0.91 & 0.000 \\
\hline
\end{tabular}

where 1 is "I disagree a lot" and 6 is "I agree a lot" 
Table 2: Respondents level of agreement/disagreement with each of these statements according to cluster

\begin{tabular}{|c|c|c|c|c|c|c|}
\hline & \multicolumn{2}{|c|}{ Cluster 1} & \multicolumn{2}{|c|}{ Cluster 2} & \multicolumn{2}{|c|}{ Cluster 3} \\
\hline & Mean & SD & Mean & SD & Mean & SD \\
\hline $\begin{array}{l}\text { The quality of the fresh produce } \\
\text { available is better in supermarkets }\end{array}$ & $5.35^{\mathrm{a}}$ & 0.93 & $4.02^{\mathrm{b}}$ & 0.99 & $3.80^{\mathrm{b}}$ & 1.23 \\
\hline $\begin{array}{l}\text { Supermarkets operate everyday while } \\
\text { traditional markets operate only on } \\
\text { certain days of the week }\end{array}$ & $5.47^{\mathrm{a}}$ & 0.74 & $4.21^{\mathrm{b}}$ & 1.31 & $4.64^{\mathrm{b}}$ & 1.47 \\
\hline $\begin{array}{l}\text { Consumers can bargain on price in wet } \\
\text { markets }\end{array}$ & $5.26^{\mathrm{a}}$ & 0.85 & $4.24^{\mathrm{b}}$ & 1.23 & $5.42^{\mathrm{a}}$ & 0.90 \\
\hline $\begin{array}{l}\text { Its more convenient to shop in } \\
\text { supermarkets because I can buy all my } \\
\text { groceries at the same time }\end{array}$ & $5.84^{\mathrm{a}}$ & 0.37 & $4.92^{\mathrm{b}}$ & 1.01 & $5.06^{\mathrm{b}}$ & 1.04 \\
\hline $\begin{array}{l}\text { I often meet my friends when I shop at } \\
\text { traditional markets }\end{array}$ & $2.97^{\mathrm{b}}$ & 1.28 & $2.65^{\mathrm{b}}$ & 1.19 & $4.05^{\mathrm{a}}$ & 1.23 \\
\hline $\begin{array}{l}\text { Supermarkets offer a wider range of } \\
\text { fresh food }\end{array}$ & $5.65^{\mathrm{a}}$ & 0.55 & $4.03^{\mathrm{b}}$ & 0.92 & $4.29^{\mathrm{b}}$ & 1.44 \\
\hline $\begin{array}{l}\text { At traditional markets, the vendors } \\
\text { remember my name }\end{array}$ & $3.31^{\mathrm{b}}$ & 1.53 & $2.47^{\mathrm{c}}$ & 1.22 & $4.54^{\mathrm{a}}$ & 1.19 \\
\hline $\begin{array}{l}\text { I cannot buy the other household items I } \\
\text { need if I shop at traditional markets }\end{array}$ & $4.81^{\mathrm{a}}$ & 1.34 & $3.68^{\mathrm{b}}$ & 1.29 & $4.46^{\mathrm{a}}$ & 1.19 \\
\hline $\begin{array}{l}\text { I go to supermarkets because of the } \\
\text { shopping points I get }\end{array}$ & $4.56^{\mathrm{a}}$ & 1.35 & $2.84^{\mathrm{c}}$ & 1.34 & $3.69^{\mathrm{b}}$ & 1.53 \\
\hline $\begin{array}{l}\text { The children feel comfortable when I } \\
\text { shop at supermarkets }\end{array}$ & $5.42^{\mathrm{a}}$ & 0.95 & $4.11^{\mathrm{b}}$ & 1.21 & $4.34^{\mathrm{b}}$ & 1.37 \\
\hline $\begin{array}{l}\text { Traditional markets seldom have a good } \\
\text { or clean environment }\end{array}$ & $5.03^{\mathrm{a}}$ & 1.19 & $3.74^{\mathrm{b}}$ & 1.05 & $4.17^{\mathrm{b}}$ & 1.29 \\
\hline $\begin{array}{l}\text { Supermarkets offer better customer } \\
\text { service than the traditional markets }\end{array}$ & $5.16^{\mathrm{a}}$ & 0.87 & $3.76^{\mathrm{c}}$ & 0.99 & $4.29^{\mathrm{b}}$ & 1.21 \\
\hline $\begin{array}{l}\text { I can return easily goods if I'm not } \\
\text { satisfied when I buy them from } \\
\text { traditional markets }\end{array}$ & $3.27^{b}$ & 1.45 & $3.03^{\mathrm{b}}$ & 0.95 & $4.41^{\mathrm{a}}$ & 1.11 \\
\hline $\begin{array}{l}\text { I buy my other household goods from } \\
\text { supermarkets but I buy my fruit and } \\
\text { vegetables from traditional markets }\end{array}$ & $3.00^{\mathrm{c}}$ & 1.32 & $3.56^{\mathrm{b}}$ & 1.05 & $4.99^{\mathrm{a}}$ & 0.97 \\
\hline $\begin{array}{l}\text { Traditional markets offer better quality } \\
\text { produce at a much cheaper price }\end{array}$ & $3.53^{b}$ & 1.35 & $3.77^{\mathrm{b}}$ & 1.06 & $5.13^{\mathrm{a}}$ & 0.92 \\
\hline $\begin{array}{l}\text { I can return easily goods that I'm not } \\
\text { satisfied with after purchasing it from } \\
\text { supermarkets }\end{array}$ & $4.32^{\mathrm{a}}$ & 1.45 & $3.31^{\mathrm{b}}$ & 1.13 & $4.14^{\mathrm{a}}$ & 1.22 \\
\hline $\begin{array}{l}\text { Fresh produce is displayed better in } \\
\text { supermarkets }\end{array}$ & $5.47^{\mathrm{a}}$ & 0.67 & $4.17^{\mathrm{c}}$ & 0.93 & $4.93^{\mathrm{b}}$ & 0.97 \\
\hline $\begin{array}{l}\text { Fruit and vegetables are fresher in } \\
\text { traditional markets }\end{array}$ & $3.37^{\mathrm{c}}$ & 1.15 & $3.82^{\mathrm{b}}$ & 0.93 & $5.19^{\mathrm{a}}$ & 0.85 \\
\hline $\begin{array}{l}\text { I prefer to buy my fresh fruit and } \\
\text { vegetables from the same vendor in the } \\
\text { traditional markets }\end{array}$ & $3.39^{\mathrm{b}}$ & 1.35 & $3.61^{\mathrm{b}}$ & 1.04 & $5.34^{\mathrm{a}}$ & 0.74 \\
\hline $\begin{array}{l}\text { Products in the supermarkets is clearly } \\
\text { priced }\end{array}$ & $5.55^{\mathrm{a}}$ & 0.64 & $4.69^{\mathrm{b}}$ & 0.97 & $4.97^{\mathrm{b}}$ & 0.79 \\
\hline $\begin{array}{l}\text { Retailers in the traditional market are } \\
\text { more knowledgeable about the products } \\
\text { they sell }\end{array}$ & $3.99^{\mathrm{b}}$ & 1.29 & $3.78^{\mathrm{b}}$ & 0.98 & $5.13^{\mathrm{a}}$ & 0.93 \\
\hline
\end{tabular}

where 1 is "I disagree a lot" and 6 is "I agree a lot"

those items with the same superscript are not significantly different at $p=0.05$ 
Table 3: Variables respondents consider in their decision to purchase fresh meat from their most preferred retail outlet

\begin{tabular}{|l|c|c|c|c|c|c|c|}
\hline & \multicolumn{9}{|c|}{ Ranking } & \multirow{2}{*}{ N } & \multirow{2}{*}{$\%$} \\
\cline { 2 - 7 } & $\mathbf{1}$ & $\mathbf{2}$ & $\mathbf{3}$ & $\mathbf{4}$ & $\mathbf{5}$ & & \\
\hline Freshness & 101 & 70 & 25 & 13 & 4 & 213 & 85.2 \\
\hline Price & 36 & 53 & 45 & 24 & 16 & 174 & 69.6 \\
\hline Cleanliness & 17 & 49 & 35 & 18 & 16 & 135 & 54.0 \\
\hline Halal & 59 & 13 & 9 & 11 & 6 & 98 & 39.2 \\
\hline Variety/a lot of choices & 3 & 12 & 17 & 19 & 12 & 63 & 25.2 \\
\hline Location - near house/office & 9 & 9 & 9 & 7 & 10 & 44 & 17.6 \\
\hline Loyalty to the same vendors & 6 & 4 & 14 & 10 & 9 & 43 & 17.2 \\
\hline Quality assurance & 4 & 8 & 9 & 6 & 3 & 30 & 12.0 \\
\hline Facilities provided & 1 & 5 & 7 & 4 & 6 & 23 & 9.2 \\
\hline Comfortable environment & 3 & 1 & 5 & 8 & 3 & 20 & 8.0 \\
\hline Size & 3 & 6 & 5 & 5 & 1 & 20 & 8.0 \\
\hline Type of shop & 1 & 3 & 7 & 2 & 6 & 19 & 7.6 \\
\hline Texture & 2 & 1 & 1 & 4 & 3 & 11 & 4.4 \\
\hline Colour & 1 & 3 & 4 & & & 8 & 3.2 \\
\hline Country-of-origin & 1 & 1 & 1 & 4 & 1 & 8 & 3.2 \\
\hline Quantity & & & 4 & 1 & 3 & 8 & 3.2 \\
\hline Intended use & 2 & & 2 & 1 & 1 & 6 & 2.4 \\
\hline No smell & 1 & 1 & 2 & & & 4 & 1.6 \\
\hline & & & & & & & \\
\hline & 250 & & & & & & \\
\hline
\end{tabular}


Table 4: Importance of variables influencing respondents' criteria of preferred retail outlet when purchasing fresh meat

\begin{tabular}{|l|c|c|}
\hline & Mean & SD \\
\hline Freshness & $5.84^{\mathrm{a}}$ & 0.39 \\
\hline Cleanliness & $5.79^{\mathrm{a}}$ & 0.48 \\
\hline Good quality produce & $5.74^{\mathrm{a}}$ & 0.56 \\
\hline A wide range of fresh produce & $5.61^{\mathrm{a}}$ & 0.60 \\
\hline I can self select & $5.52^{\mathrm{a}}$ & 0.78 \\
\hline All product is clearly priced & $5.51^{\mathrm{a}}$ & 0.77 \\
\hline Value for money & $5.51^{\mathrm{a}}$ & 0.74 \\
\hline A wide range of other fresh products & $5.49^{\mathrm{a}}$ & 0.72 \\
\hline Product easily accessible & $5.44^{\mathrm{a}}$ & 0.79 \\
\hline Competitive price & $5.42^{\mathrm{a}}$ & 0.96 \\
\hline Product is clearly labelled & $5.39^{\mathrm{a}}$ & 0.89 \\
\hline Good customer service/friendly staff & $5.28^{\mathrm{a}}$ & 0.85 \\
\hline Quick/fast checkout & $5.26^{\mathrm{a}}$ & 0.98 \\
\hline Fresh produce is refrigerated & $5.25^{\mathrm{a}}$ & 0.94 \\
\hline A lot of sections (wet and dry sections) & $5.24^{\mathrm{a}}$ & 0.95 \\
\hline Everything all under one roof & $5.19^{\mathrm{a}}$ & 0.98 \\
\hline Origin of the product is clearly displayed & $5.10^{\mathrm{b}}$ & 1.06 \\
\hline Well organised/well laid out & $5.10^{\mathrm{b}}$ & 0.96 \\
\hline Offer special prices or discounts & $5.06^{\mathrm{c}}$ & 1.11 \\
\hline Local produce & $5.06^{\mathrm{c}}$ & 1.03 \\
\hline Easy parking & $5.04^{\mathrm{c}}$ & 1.01 \\
\hline Trading hours & $5.00^{\mathrm{c}}$ & 0.96 \\
\hline Knowledgeable staff & $5.00^{\mathrm{c}}$ & 1.02 \\
\hline Near my house/work place & $4.91^{\mathrm{d}}$ & 1.04 \\
\hline Loyalty/always shop there & $4.75^{\mathrm{e}}$ & 1.12 \\
\hline Attractive display/presentation & $4.73^{\mathrm{e}}$ & 1.03 \\
\hline Opportunity to bargain on price & $4.70^{\mathrm{e}}$ & 1.16 \\
\hline Trolley and baskets are provided & $4.68^{\mathrm{e}}$ & 1.41 \\
\hline Return/refund policy & $4.66^{\mathrm{e}}$ & 1.14 \\
\hline Sample of the product & $4.23^{\mathrm{f}}$ & 1.32 \\
\hline Air-conditioned & $4.21^{\mathrm{f}}$ & 1.52 \\
\hline Advertising on radio/tv/newspaper & $3.69^{\mathrm{g}}$ & 1.31 \\
\hline Credit facilities & $3.55^{\mathrm{h}}$ & 1.64 \\
\hline Shopping points/loyalty programs & $3.53^{\mathrm{h}}$ & 1.46 \\
\hline Cater for kids & $3.52^{\mathrm{h}}$ & 1.58 \\
\hline w & & \\
\hline
\end{tabular}

where 1 is "not at all important" and 6 is "very important"

those items with the same superscript are not significantly different at $p=0.05$ 
Table 5: Factors influencing respondents' criteria of preferred retail outlet

\begin{tabular}{|c|c|c|c|c|c|}
\hline & \multicolumn{5}{|c|}{ Factor } \\
\hline & 1 & 2 & 3 & 4 & 5 \\
\hline Product easily accessible & 0.855 & & & & \\
\hline Product is clearly labelled & 0.765 & & & & \\
\hline Quick fast checkout & 0.734 & & & & \\
\hline Local produce & 0.668 & & & & \\
\hline $\begin{array}{l}\text { Origin of the product is clearly } \\
\text { displayed }\end{array}$ & 0.647 & & & & \\
\hline Trading hours & 0.625 & & & & \\
\hline Loyalty/always shop there & 0.603 & & & & \\
\hline Air-conditioned & & 0.746 & & & \\
\hline Advertising on radio/tv/ newspaper & & 0.737 & & & \\
\hline Cater for kids & & 0.737 & & & \\
\hline Trolley and baskets are provided & & 0.697 & & & \\
\hline Credit facilities & & 0.686 & & & \\
\hline Shopping points/loyalty programs & & 0.635 & & & \\
\hline Good quality produce & & & 0.818 & & \\
\hline Freshness & & & 0.790 & & \\
\hline Clean & & & 0.707 & & \\
\hline Everything all under one roof & & & & 0.726 & \\
\hline Near my house/work place & & & & 0.720 & \\
\hline Easy parking & & & & 0.712 & \\
\hline Opportunity to bargain on price & & & & & 0.692 \\
\hline Eigenvalue & 6.584 & 2.204 & 1.462 & 1.347 & 1.106 \\
\hline Percent variance & 19.67 & 17.11 & 10.76 & 9.77 & 6.19 \\
\hline Cumulative variance & 19.67 & 36.78 & 47.54 & 57.32 & 63.51 \\
\hline Cronbach's alpha & 0.858 & 0.838 & 0.736 & 0.664 & \\
\hline Factor mean & $5.15^{\mathrm{b}}$ & $3.87^{\mathrm{d}}$ & $5.79^{a}$ & $5.05^{\mathrm{b}}$ & $4.70^{\mathrm{c}}$ \\
\hline
\end{tabular}

where those items with the same superscript are not significantly different at $p=0.05$

Table 6: Results of principal component analysis (criteria of preferred retail outlet) by cluster

\begin{tabular}{|l|c|c|c|c|c|}
\hline & \multicolumn{2}{|c|}{ Cluster 1 } & \multicolumn{2}{c|}{ Cluster 2 } & \multirow{2}{*}{ Sig. } \\
\cline { 2 - 5 } & Mean & SD & Mean & SD & \\
\hline Factor 1: Perceived risk & 5.11 & 0.73 & 5.14 & 0.68 & 0.713 \\
\hline Factor 2: Characteristics of a modern retail outlet & 4.19 & 0.99 & 3.81 & 1.07 & 0.006 \\
\hline Factor 3: Quality & 5.78 & 0.40 & 5.81 & 0.39 & 0.592 \\
\hline Factor 4: Convenience & 5.29 & 0.86 & 5.00 & 0.90 & 0.013 \\
\hline Factor 5: Price & 4.50 & 1.29 & 4.88 & 1.04 & 0.019 \\
\hline
\end{tabular}


Table 7: Variables respondents consider in their decision to purchase fresh fruit and vegetables from their most preferred retail outlet

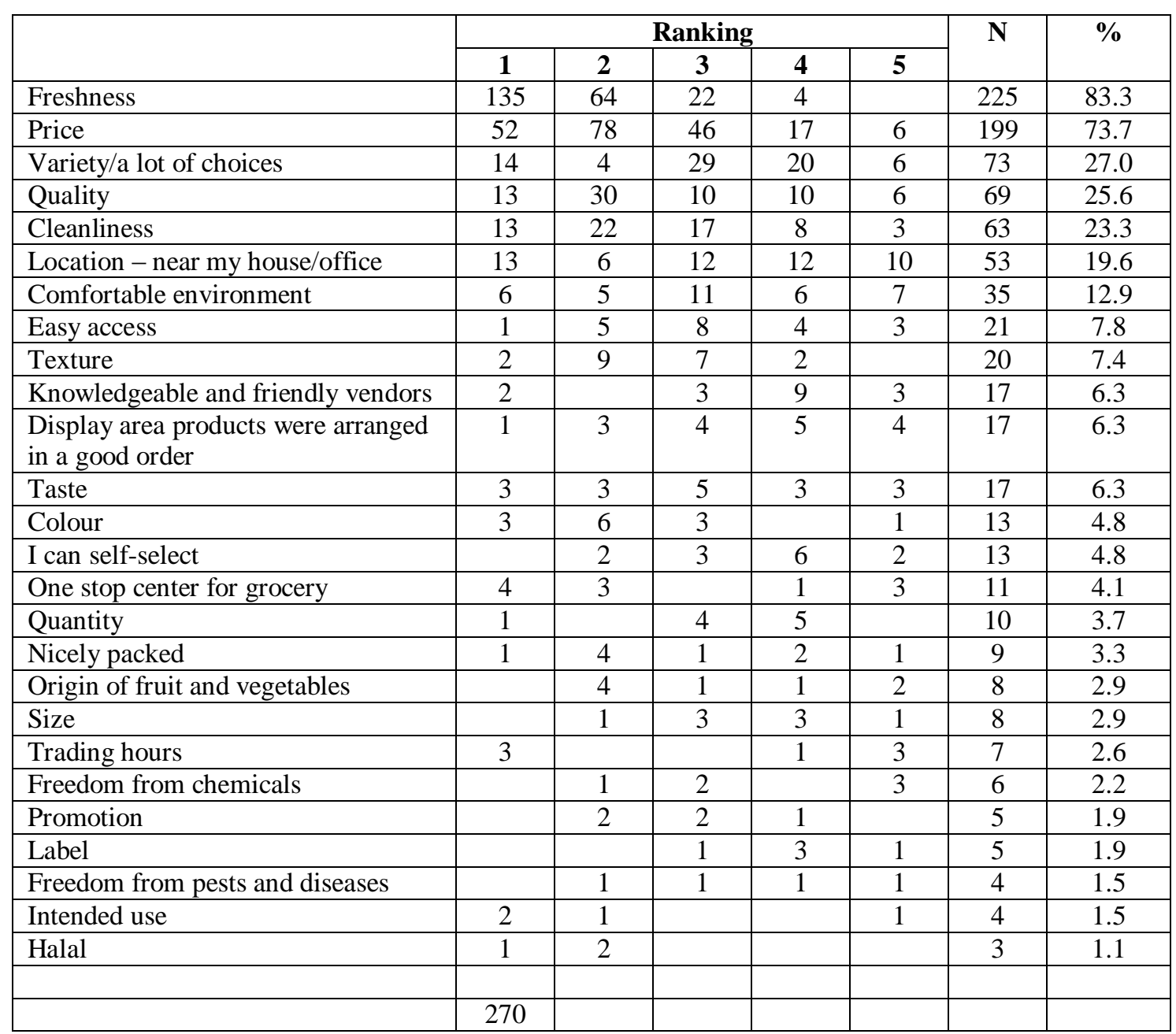


Table 8: Importance of variables influencing respondents' criteria of preferred retail outlet when purchasing fresh fruit and vegetables

\begin{tabular}{|l|c|c|}
\hline & Mean & SD \\
\hline Freshness & $5.77^{\mathrm{a}}$ & 0.58 \\
\hline Cleanliness & $5.66^{\mathrm{a}}$ & 0.65 \\
\hline Good quality produce & $5.64^{\mathrm{a}}$ & 0.66 \\
\hline A wide range of fresh produce & $5.51^{\mathrm{a}}$ & 0.78 \\
\hline I can self select & $5.45^{\mathrm{a}}$ & 0.83 \\
\hline Value for money & $5.44^{\mathrm{a}}$ & 0.79 \\
\hline A wide range of other fresh products & $5.41^{\mathrm{a}}$ & 0.82 \\
\hline All product is clearly priced & $5.37^{\mathrm{a}}$ & 0.86 \\
\hline Competitive price & $5.37^{\mathrm{a}}$ & 0.88 \\
\hline Product easily accessible & $5.30^{\mathrm{a}}$ & 0.86 \\
\hline Product is clearly labelled & $5.29^{\mathrm{a}}$ & 0.89 \\
\hline Good customer service/friendly staff & $5.25^{\mathrm{a}}$ & 0.87 \\
\hline Quick/fast checkout & $5.23^{\mathrm{a}}$ & 0.99 \\
\hline Fresh produce is refrigerated & $5.16^{\mathrm{a}}$ & 1.02 \\
\hline A lot of sections (wet and dry sections) & $5.14^{\mathrm{a}}$ & 1.03 \\
\hline Everything all under one roof & $5.14^{\mathrm{a}}$ & 1.02 \\
\hline Well organised/well laid out & $5.10^{\mathrm{b}}$ & 0.95 \\
\hline Easy parking & $5.08^{\mathrm{b}}$ & 1.06 \\
\hline Offer special prices or discounts & $5.06^{\mathrm{b}}$ & 1.02 \\
\hline Near my house/work place & $4.95^{\mathrm{c}}$ & 1.03 \\
\hline Knowledgeable staff & $4.90^{\mathrm{c}}$ & 1.05 \\
\hline Trading hours & $4.89^{\mathrm{c}}$ & 1.08 \\
\hline Origin of the product is clearly displayed & $4.84^{\mathrm{d}}$ & 1.19 \\
\hline Attractive display/presentation & $4.77^{\mathrm{e}}$ & 1.08 \\
\hline Local produce & $4.74^{\mathrm{f}}$ & 1.15 \\
\hline Trolley and baskets are provided & $4.72^{\mathrm{g}}$ & 1.38 \\
\hline Loyalty/always shop there & $4.67^{\mathrm{g}}$ & 1.15 \\
\hline Opportunity to bargain on price & $4.47^{\mathrm{h}}$ & 1.41 \\
\hline Return/refund policy & $4.37^{\mathrm{i}}$ & 1.34 \\
\hline Sample of the product & $4.35^{\mathrm{i}}$ & 1.25 \\
\hline Air-conditioned & $4.22^{\mathrm{j}}$ & 1.51 \\
\hline Credit facilities & $3.88^{\mathrm{k}}$ & 1.56 \\
\hline Advertising on radio/tv/newspaper & $3.74^{\mathrm{l}}$ & 1.42 \\
\hline Cater for kids & $3.63^{\mathrm{m}}$ & 1.54 \\
\hline Shopping points/loyalty programs & $3.46^{\mathrm{n}}$ & 1.52 \\
\hline
\end{tabular}

where 1 is "not at all important" and 6 is "very important"

those items with the same superscript are not significantly different at $p=0.05$ 
Table 9: Factors influencing respondents' criteria of preferred retail outlet

\begin{tabular}{|c|c|c|c|c|}
\hline \multirow[t]{2}{*}{ Variable } & \multicolumn{4}{|c|}{ Factor } \\
\hline & 1 & 2 & 3 & 4 \\
\hline A wide range of fresh produce & 0.846 & & & \\
\hline A wide range of other fresh produce & 0.824 & & & \\
\hline Product is easily accessible & 0.761 & & & \\
\hline All product is clearly priced & 0.758 & & & \\
\hline Product is clearly labelled & 0.726 & & & \\
\hline Good quality produce & 0.717 & & & \\
\hline I can self select & 0.703 & & & \\
\hline Advertising on radio/tv/newspaper & & 0.813 & & \\
\hline Shopping points/loyalty programs & & 0.772 & & \\
\hline Cater for kids & & 0.755 & & \\
\hline Air-conditioned & & 0.714 & & \\
\hline Return/refund policy & & 0.642 & & \\
\hline Credit facilities & & 0.636 & & \\
\hline Easy parking & & & 0.767 & \\
\hline Everything all under one roof & & & 0.721 & \\
\hline Near my house/work place & & & 0.608 & \\
\hline Competitive price & & & & 0.778 \\
\hline Value for money & & & & 0.663 \\
\hline Opportunity to bargain on price & & & & 0.630 \\
\hline Eigenvalue & 7.295 & 2.550 & 1.306 & 1.113 \\
\hline Percent variance & 24.69 & 18.84 & 11.15 & 9.87 \\
\hline Cumulative variance & 24.69 & 43.53 & 54.68 & 64.55 \\
\hline Cronbach's alpha & 0.906 & 0.851 & 0.714 & 0.643 \\
\hline Factor mean & $5.43^{\mathrm{a}}$ & $3.88^{\mathrm{c}}$ & $5.06^{\mathrm{b}}$ & $5.09^{\mathrm{b}}$ \\
\hline
\end{tabular}

where those items with the same superscript are not significantly different at $p=0.05$

Table 10: Results of principal component analysis (criteria of preferred retail outlet) by cluster

\begin{tabular}{|l|c|c|c|c|c|c|}
\hline \multirow{2}{*}{} & \multicolumn{2}{|c|}{ Cluster 1 } & \multicolumn{2}{c|}{ Cluster 2 } & \multicolumn{2}{c|}{ Cluster 3 } \\
\cline { 2 - 7 } & Mean & SD & Mean & SD & Mean & SD \\
\hline Factor 1:Perceived risk & $5.65^{\mathrm{a}}$ & 0.48 & $5.03^{\mathrm{b}}$ & 0.81 & $5.59^{\mathrm{a}}$ & 0.44 \\
\hline Factor 2:Modern retail outlet & $4.32^{\mathrm{a}}$ & 0.97 & $3.44^{\mathrm{b}}$ & 1.11 & $3.93^{\mathrm{a}}$ & 1.11 \\
\hline Factor 3:Convenience & $5.27^{\mathrm{a}}$ & 0.75 & $4.81^{\mathrm{b}}$ & 0.91 & $5.11^{\mathrm{a}}$ & 0.76 \\
\hline Factor 4:Value & $5.13^{\mathrm{a}}$ & 0.77 & $4.73^{\mathrm{b}}$ & 0.88 & $5.39^{\mathrm{a}}$ & 0.58 \\
\hline
\end{tabular}

